\title{
Correction to: Hospital-based headache care during the Covid-19 pandemic in Denmark and Norway
}

Espen Saxhaug Kristoffersen ${ }^{1,2^{*}}$, Kashif Waqar Faiz ${ }^{1}$, Else Charlotte Sandset ${ }^{3,4}$, Anette Margrethe Storstein ${ }^{5}$, Simon Stefansen ${ }^{6}$, Bendik Slagsvold Winsvold ${ }^{3,7 \dagger}$ and Jakob Møller Hansen ${ }^{6,8 \dagger}$

\section{Correction to: J Headache Pain 21, 128 (2020) https://doi.org/10.1186/s10194-020-01195-2}

Following publication of the original article [1], we were notified that the author names should have been presented in their full given name and last name, not with initials.

The original article has been corrected.

\begin{abstract}
Author details
'Department of Neurology, Akershus University Hospital, PO Box 1000, 1478 Lørenskog, Norway. ${ }^{2}$ Department of General Practice, University of Oslo, Oslo, Norway. ${ }^{3}$ Department of Neurology, Oslo University Hospital, Oslo, Norway. ${ }^{4}$ The Norwegian Air Ambulance Foundation, Oslo, Norway. ${ }^{5}$ Department of Neurology, Haukeland University Hospital, Bergen, Norway. ${ }^{6}$ National Headache Knowledge Center, Rigshospitalet, Copenhagen, Denmark. ${ }^{7}$ Department of Research, Innovation and Education, Division of Clinical Neuroscience, Oslo University Hospital, Oslo, Norway. ${ }^{8}$ Danish Headache Center, Glostrup - University of Copenhagen, Copenhagen, Denmark.
\end{abstract}

Published online: 16 November 2020

\section{Reference}

1. Kristoffersen et al (2020) Hospital-based headache care during the Covid-19 pandemic in Denmark and Norway. J Headache Pain 21:128. https://doi.org/10. 1186/s10194-020-01195-2

\footnotetext{
The original article can be found online at https://doi.org/10.1186/s10194020-01195-2.

* Correspondence: e.s.kristoffersen@medisin.uio.no

${ }^{+}$Bendik Slagsvold Winsvold and Jakob Møller Hansen contributed equally to this work.

'Department of Neurology, Akershus University Hospital, PO Box 1000, 1478

Lørenskog, Norway

${ }^{2}$ Department of General Practice, University of Oslo, Oslo, Norway

Full list of author information is available at the end of the article
}

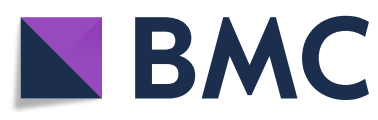

( The Author(s). 2020 Open Access This article is licensed under a Creative Commons Attribution 4.0 International License, which permits use, sharing, adaptation, distribution and reproduction in any medium or format, as long as you give appropriate credit to the original author(s) and the source, provide a link to the Creative Commons licence, and indicate if changes were made. The images or other third party material in this article are included in the article's Creative Commons licence, unless indicated otherwise in a credit line to the material. If material is not included in the article's Creative Commons licence and your intended use is not permitted by statutory regulation or exceeds the permitted use, you will need to obtain permission directly from the copyright holder. To view a copy of this licence, visit http://creativecommons.org/licenses/by/4.0/. The Creative Commons Public Domain Dedication waiver (http://creativecommons.org/publicdomain/zero/1.0/) applies to the data made available in this article, unless otherwise stated in a credit line to the data. 